\title{
Biochar and wheat straw affecting soil chemistry and microbial biomass carbon countrywide
}

\author{
Younes Shokuhifar ${ }^{1} \cdot$ Ahmad Mohammadi Ghahsareh $^{1} \cdot \operatorname{Karim}_{\text {Shahbazi }}{ }^{1} \cdot$ Mohammad Mehdi Tehrani $^{2}$. \\ Hossein Besharati $^{2}$
}

Received: 5 February 2021 / Revised: 23 March 2021 / Accepted: 23 March 2021 / Published online: 1 May 2021

(C) The Author(s) 2021

\begin{abstract}
Indicating how different sources of organic matter $(\mathrm{OM})$ may affect the properties of a wide range of soil types, at varying soil moisture (SM), is of significance in the agricultural fields. A large dataset of soil samples $(0-30 \mathrm{~cm})$ was collected from different parts of Iran (21 different agricultural regions, with a wide range of physical, chemical, and biological properties) to determine the effects of OM and varying SM on soil chemical ( $\mathrm{pH}$, salinity, and organic carbon) and biological (microbial biomass carbon, MBC) properties. The collected soil samples were incubated (9-month period) with the experimental treatments including OM (control (M1), 2\% wheat straw (WS) (M2), and 2\% biochar (BI) (M3)), at different SM levels (0.2 field capacity, FC (V1), 0.7 variable $\mathrm{FC}(\mathrm{V} 2), 0.7$ constant $\mathrm{FC}(\mathrm{V} 3)$, and saturated moisture $(\mathrm{V} 4))$. Wheat straw was pyrolyzed $\left(\mathrm{at}^{5} 500^{\circ} \mathrm{C}\right)$ to produce $\mathrm{BI}$, and their chemical properties were determined. BI salinity $(3.1 \mathrm{dS} / \mathrm{m})$ was significantly higher than WS $(2.8 \mathrm{dS} / \mathrm{m})$. The organic treatments, especially BI, significantly increased soil OM and MBC compared with the control treatment. The two sources of organic fertilization increased soil $\mathrm{pH}, \mathrm{OM}$, and $\mathrm{MBC}$, though such effects were functions of varying soil moisture (drying and rewetting cycles). Due to higher C percentage $(61 \%)$, the effects of BI, significantly affected by soil moisture, were more pronounced on soil parameters. The tested sources of organic matter (WS and BI), acting as functions of soil moisture, can strongly affect soil chemical and biological properties and contribute to higher efficiency of agricultural fields.
\end{abstract}

Keywords Field capacity $\cdot$ Organic matter $\cdot$ Pyrolysis $\cdot$ Soil acidity $\cdot$ Soil chemical and biological properties $\cdot$ Soil salinity

\section{Introduction}

With respect to the world increasing population and the necessity for increasing the production of agricultural fields, the improvement of soil proprieties, especially in the arid and semi-arid areas of the world, is of significance [48]. To enhance soil properties, different methods including chemical and biological fertilization have been so far tested and used $[45,46,56]$. Although chemical fertilization is a quick method of providing crop with its required nutrients, it is not economically and environmentally recommendable, as it is subjected to leaching and can negatively affect the environment $[3,32]$.

Ahmad Mohammadi Ghahsareh

amohammadi@khuisf.ac.ir

1 Department of Soil Science, Isfahan (Khorasgan) Islamic Azad University, Isfahan, Iran

2 Agricultural Research, Education and Extension Organization (AREEO), Soil and Water Research Institute, Karaj, Iran
Accordingly, the use of organic fertilization including manure, organic matter, and soil microbes may be superior to chemical fertilization, as they can significantly enhance soil properties and are economically and environmentally recommendable $[24,35]$. In the semi-arid and arid areas of the world, organic matter deficiency decreases plant growth and yield production [6]. For example, in most agricultural fields in Iran, the rate of organic carbon is less than 1\% [43].

The accuracy of results and analyses may increase, if a wide range of soil types (different physical, chemical, and biological properties), as tested in this research, are subjected to the experimental treatments. Biochar (BI) and wheat straw (WS) are among the most prevalent sources of organic matter [27, 49]. WS as a source of organic matter (cultivating WS into the soil after harvest in reduced or no tillage) can considerably enhance soil nutrients including carbon. However, a major disadvantage of using WS is its high rate of carbon/nitrogen $(\mathrm{C} / \mathrm{N})$, which decreases the availability of soil $\mathrm{N}$ for plant use, due to $\mathrm{N}$ microbial immobilization [7]. 
Biochar (produced by the pyrolyzation of agricultural residues) is an organic source of nutrients for plant use and can (1) improve different soil physical, chemical, and biological properties and (2) enhances carbon sequestration, which results in the mitigation of climate change. Biochar can absorb soil organic matter and hence preserve it from leaching. Due to its specific physical properties, especially its high porosity, BI can significantly enhance soil sorption and immobilization of organic matter $[10,37,53]$. Although it has not been the case for the present research, usually the rate of $\mathrm{C} / \mathrm{N}$ in $\mathrm{BI}$ is less than WS, as BI contains higher N, preventing the deficiency of nutrients (faster rate of decomposition) including $\mathrm{N}$ in the soil $[1,23]$. Carbon sequestration in the form of soil organic matter not only affects soil productivity but also increases atmosphere $\mathrm{CO}_{2}$ (greenhouse gas) affecting the global climate [42].

Different parameters such as soil moisture (soil drying and rewetting) may affect soil $\mathrm{N}$ and $\mathrm{C}$ cycling and dynamic including microbial biomass carbon [30]. There is not much data, to our knowledge, on such processes in the soil. The significance of soil drying and rewetting cycles is due to affecting different soil processes including (1) formation of soil aggregates, (2) humus decomposition, (3) respiration of soil, (4) soil microbial population, and (5) nutrient cycling [20,40]. Accordingly, it is important to investigate how the combination of different types of organic matter and soil moisture may affect soil physical, chemical, and biological properties.

Although there has been previous research on the use of biochar for the improvement of soil physical, chemical, and biological properties $[4,21,22]$, it is yet a matter of question how biochar use may enhance soil properties, compared with the use of raw organic matter (wheat straw) at varying levels of soil moisture. Accordingly, because the investigation of soil chemical and biological properties affected by soil moisture dynamic (drying and rewetting) and sources of organic matter is of significance for the proper production of agricultural crops in the semi-arid and arid areas of the world, this research was proposed using a large set of soil data. The objective was to determine the effects of soil moisture levels and sources of organic fertilization (WS and $\mathrm{BI}$ ) on soil chemical properties $(\mathrm{pH}$, salinity, and organic matter) and soil biological properties (microbial biomass carbon) using a large dataset of soil samples collected countrywide.

\section{Materials and methods}

\subsection{Sampling}

The soil samples were collected from 21 different agricultural regions across Iran (Fig. 1), and their physical and chemical properties were determined (Table 1). The sampling regions, namely, (1) DarehBid, (2) Lenjan, (3) Talkhuncheh, (4) Darin,
(5) Balestan, (6) Bushgan, (7) EmamZadeh, (8) GhasemKhani, (9) EbrahimAbad, (10) GonAbad, (11) NajmAbad, (12) Jazooshi, (13) Kharghani, (14) Sarvestan, (15) Dogh, (16) Shurjeh, (17) Ghadamgah, (18) CamSorkh, (19) SharifAbad, (20) TappehGhachi, and (21) Sahel, were used for the experiment. The samples were taken from the depth of 0-30 cm, air dried, and passed through a 2-mm mesh, and their physical and chemical properties including saturation percentage (SP), field moisture capacity, soil texture, salinity $(\mathrm{EC}, \mathrm{dS} / \mathrm{m}), \mathrm{pH}$, organic carbon (OC), calcium carbonate $(\mathrm{CaCO} 3)$, available phosphorous $(\mathrm{P})$, iron $(\mathrm{Fe})$, zinc $(\mathrm{Zn})$, and cation exchange capacity (CEC) were determined in the laboratory of Soil and Water Research Institute, Karaj, Iran, using the standard methods [33] (Table 1).

\subsection{Biochar and wheat straw}

For the production of BI, first wheat straw was precisely weighed, inserted in metal containers, and sealed with a lid and, to avoid air penetration, was covered with an aluminum seal. The container was then heated to $500^{\circ} \mathrm{C}$ [18] for $3 \mathrm{~h}$ using a furnace. The produced BI, which was without any ash, was weighed and meshed using a 2-mm mesh. WS salinity was also little, indicating that the straw was produced under anaerobic conditions [26]. WS and BI properties were determined using the standard methods [33]. The wheat straw had a $\mathrm{pH}$ and salinity of 5.74 and $4.96(\mathrm{dS} / \mathrm{m})$, respectively, and contained carbon $(\mathrm{C})$ of $53.74 \%$, hydrogen $(\mathrm{H})$ of $3.53 \%$, total nitrogen $(\mathrm{N})$ of $0.61 \%$, and total potassium $(\mathrm{K})$ of $1.52 \%$. The properties of $\mathrm{BI}$ were according to the following: $\mathrm{C}$ at $61 \%, \mathrm{H}$ at $3.5 \%$, and total $\mathrm{N}$ at $0.5 \%$. The percentage of biochar yield $(62 \%)$ was calculated using Eq. 1:

Biochar yield $(\%)=$

$($ weight of produced biochar $(\mathrm{g})) /($ initial dry weight $(\mathrm{g})) \times 100$ )

\subsection{Experimental design}

The incubation experiment was a factorial on the basis of a completely randomized design including organic matter at three levels (control (M1), 2\% WS (M2), 2\% BI (M3)) and moisture levels (0.2 field capacity (FC) (V1), 0.7 variable FC (V2), 0.7 constant FC (V3), and saturated moisture (V4)) with three replicates in a constant temperature for the 21 regions. The moisture of the pots was kept constant on a weight basis. During the 9-month incubation period, the effects of organic matter and moisture levels on soil $\mathrm{pH}$, salinity, organic carbon, and microbial biomass carbon were determined. 


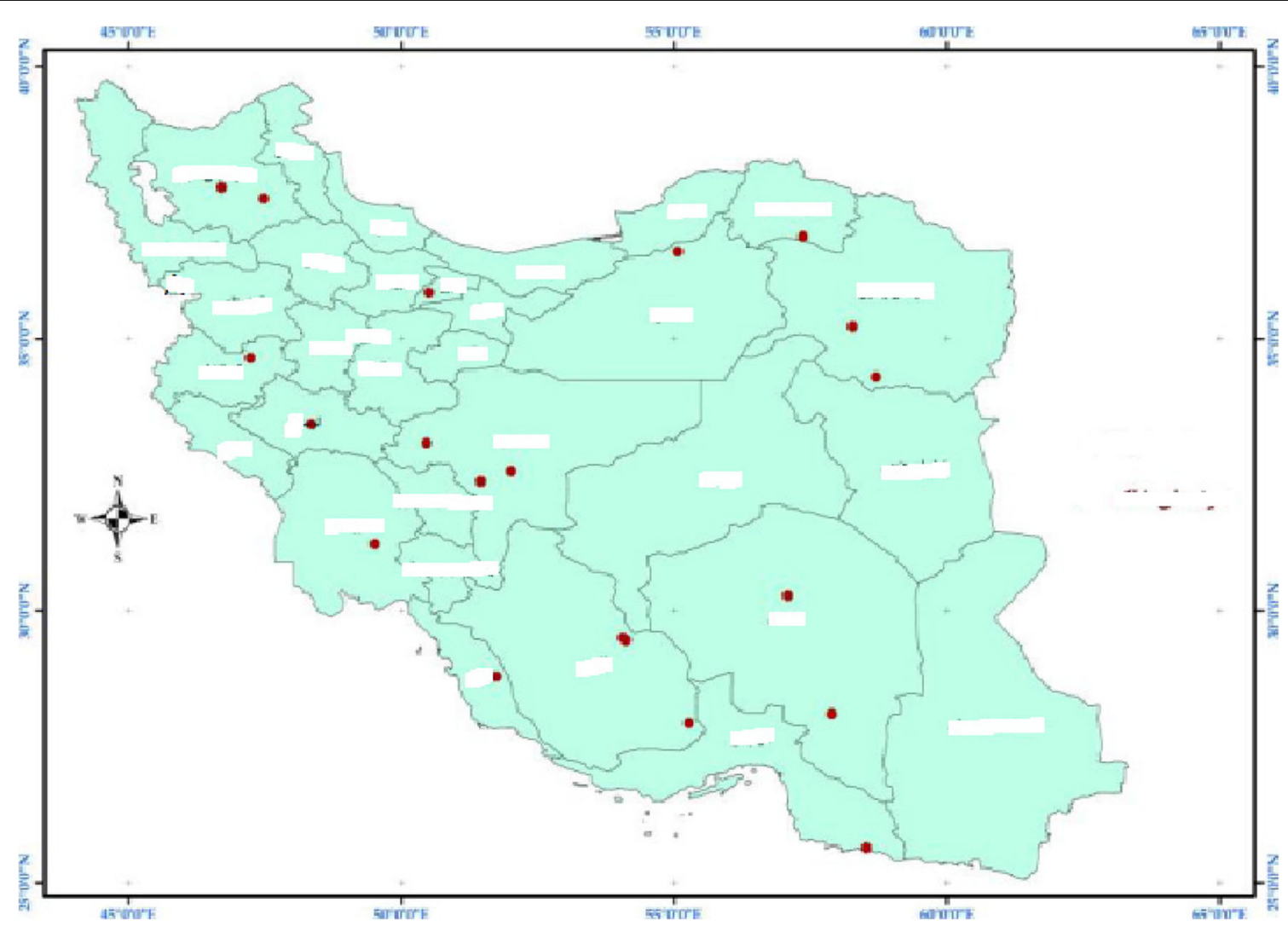

Fig. 1 The experimental sites

\subsection{Measuring microbial biomass carbon}

Microbial biomass carbon (MBC) was measured by the fumigation method using two 25 -g soil samples. One sample was treated with $100-\mathrm{ml}$ potassium sulfate $(0.5 \mathrm{M})$ using a $250-\mathrm{ml}$ Erlenmeyer, and the other one was poured into a 50-ml container and inserted in a desiccator covered with a filter paper at the bottom along with a container of soda lime and a container of $25-\mathrm{ml}$ chloroform. The desiccator was connected to a vacuum pump boiling the chloroform for $2 \mathrm{~min}$. The dedicator was placed in the dark for $24 \mathrm{~h}$, and then the fumigated samples with chloroform were connected to the vacuum pump to evaporate the remaining of chloroform.

The samples were then mixed with $100-\mathrm{ml}$ potassium sulfate and along with a control sample (without chloroform) were shaken for $45 \mathrm{~min}$ using a reciprocal shaker at $40 \mathrm{round} / \mathrm{min}$. The suspension was filtered with a Whatman paper \#42. Microbial biomass carbon was determined using $8 \mathrm{ml}$ of the extract treated with $2 \mathrm{ml}$ potassium-dichromate and $15 \mathrm{ml}$ concentrated sulfuric and phosphoric acid, under reflux conditions for $30 \mathrm{~min}$. The sample was then treated with $25 \mathrm{ml}$ water and, after adding ortho-phenanthroline iron (II) sulfate, was titrated with ammonium sulfate, and the remaining of potassium dichromate was measured [19].

\subsection{Statistical analysis}

Data were subjected to analysis of variance using SAS. Data were also subjected to a factorial analysis with the two factors of moisture and organic matter. The figures were accordingly plotted using SAS PROC PLOT. The normality of data was analyzed using Proc Univariate (Shapiro-Wilks tests). The homogeneity of variance was also tested using Levene's test. There was not any use of alternative analysis as the data were not subjected to any type of transformation. Means were compared using Duncan multiple range test at $P=0.05$. The map of the experimental regions was drawn using ARC-GIS.

\section{Results}

\subsection{Soil physical and chemical properties}

The physical and chemical properties of the soils (Table 1), which were highly variable, were determined in the regions with the Eastern latitudes ranging from $25^{\circ} 38^{\prime}$ to $65^{\circ} 35^{\prime}$ and northern longitudes ranging from $38^{\circ} 12^{\prime}$ to $59^{\circ} 4^{\prime}$. The soils had different types of texture, with the SP ranging from 22 to $54 \%$, and a wide range of salinity $(0.11-23.6 \mathrm{dS} / \mathrm{m})$ levels, and the $\mathrm{pH}$ values ranging from 7.57 to 8.33 . The soils were 
Table 1 The physical and chemical properties of the experimental soils

\begin{tabular}{|c|c|c|c|c|c|c|c|c|c|c|c|c|c|}
\hline Ion & Altitude & Longitude & $\begin{array}{l}\text { EC (1:5) } \\
(\mathrm{dS} / \mathrm{m})\end{array}$ & $\mathrm{pH}$ & S.P. & $\begin{array}{l}\text { O.C. } \\
(\%)\end{array}$ & $\begin{array}{l}\text { Avail. P. } \\
(\mathrm{mg} / \mathrm{kg})\end{array}$ & $\begin{array}{l}\mathrm{Fe} \\
(\mathrm{mg} / \mathrm{kg})\end{array}$ & $\begin{array}{l}\mathrm{Zn} \\
(\mathrm{mg} / \mathrm{kg})\end{array}$ & $\begin{array}{l}\text { CEC (meq/ } \\
100 \mathrm{~g})\end{array}$ & $\begin{array}{l}\mathrm{CaCO} 3 \\
(\%)\end{array}$ & $\begin{array}{l}\text { Avail. S } \\
\text { (mg/kg) }\end{array}$ & Texture \\
\hline 1 & $33^{\circ} 04^{\prime}$ & $50^{\circ} 27^{\prime}$ & 0.11 & 7.83 & 38 & 0.54 & 20.2 & 8.8 & 0.5 & 23.4 & 14.9 & 2 & S.C. \\
\hline 2 & $32^{\circ} 34^{\prime}$ & $52^{\circ} 00^{\prime}$ & 8.06 & 7.92 & 41 & 0.56 & 13 & 6.3 & 0.6 & 14.2 & 34.3 & 837.5 & S.C.L. \\
\hline 3 & $32^{\circ} 22^{\prime}$ & $51^{\circ} 27^{\prime}$ & 0.16 & 7.98 & 17 & 0.06 & 6 & 5.8 & 1.9 & 7 & 84.2 & 10.25 & L.S. \\
\hline 4 & $37^{\circ} 34^{\prime}$ & $47^{\circ} 29^{\prime}$ & 0.18 & 7.72 & 49 & 0.61 & 4 & 7.6 & 0.3 & 28.6 & 6.3 & 7.75 & C.L. \\
\hline 5 & $37^{\circ} 46^{\prime}$ & $46^{\circ} 42^{\prime}$ & 0.15 & 7.61 & 28 & 0.68 & 10 & 7.3 & 0.4 & 13.6 & 0.96 & 4.25 & S.L. \\
\hline 6 & $50^{\circ} 57^{\prime}$ & $48^{\circ} 48^{\prime}$ & 2.67 & 7.76 & 47 & 0.88 & 3.46 & 6 & 0.5 & 14.6 & 49.9 & 356.25 & S.C. \\
\hline 7 & $28^{\circ} 47^{\prime}$ & $51^{\circ} 42^{\prime}$ & 1.08 & 7.66 & 34 & 0.84 & 7.2 & 3.7 & 0.8 & 9.2 & 63.4 & 194.25 & L. \\
\hline 8 & $28^{\circ} 47^{\prime}$ & $51^{\circ} 44^{\prime}$ & 0.27 & 7.94 & 37 & 0.22 & 7.6 & 4 & 0.2 & 10.6 & 45.8 & 12.75 & L. \\
\hline 9 & $52^{\circ} 56^{\prime}$ & $40^{\circ} 85^{\prime}$ & 12.66 & 7.57 & 39 & 0.22 & 13 & 6.3 & 0.6 & 14.2 & 21 & 8.7 & C.L. \\
\hline 10 & $50^{\circ} 83^{\prime}$ & $40^{\circ} 90^{\prime}$ & 0.2 & 7.94 & 34 & 0.06 & 11.4 & 3.7 & 0.6 & 9.6 & 16.6 & 7.75 & L. \\
\hline 11 & $65^{\circ} 35^{\prime}$ & $38^{\circ} 12^{\prime}$ & 0.18 & 8.18 & 22 & 0.08 & 3.6 & 5.9 & 0.2 & 7.4 & 8.4 & 9 & L.S. \\
\hline 12 & $31^{\circ} 13^{\prime}$ & 49 o $31^{\prime}$ & 23.6 & 8.33 & 44 & 0.7 & 1.6 & 0.8 & 0.6 & 9.2 & 9.2 & 7.9 & S.L. \\
\hline 13 & $36^{\circ} 35^{\prime}$ & $55^{\circ} 04^{\prime}$ & 3.99 & 7.81 & 36 & 0.77 & 10.6 & 11.4 & 0.5 & 15.2 & 32.4 & 511 & S.C. \\
\hline 14 & $29^{\circ} 29^{\prime}$ & $54^{\circ} 03^{\prime}$ & 4.27 & 7.81 & 39 & 0.3 & 2 & 2.4 & 0.2 & 10.8 & 21.7 & 1110 & S.L. \\
\hline 15 & $29^{\circ} 27^{\prime}$ & $59^{\circ} 04^{\prime}$ & 0.25 & 7.87 & 42 & 0.87 & 16.4 & 12.5 & 1 & 18.8 & 39.4 & 7.5 & C.L. \\
\hline 16 & $27^{\circ} 56^{\prime}$ & $55^{\circ} 16^{\prime}$ & 0.23 & 7.74 & 30 & 0.81 & 5.8 & 5.5 & 0.3 & 9.2 & 37.5 & 10.5 & S.L. \\
\hline 17 & $27^{\circ} 45^{\prime}$ & $57^{\circ} 01^{\prime}$ & 0.14 & 7.99 & 33 & 0.34 & 2.0 & 3.5 & 0.3 & 7.6 & 29.2 & 3.25 & Si.L. \\
\hline 18 & $28^{\circ} 06^{\prime}$ & $57^{\circ} 53^{\prime}$ & 1.15 & 7.96 & 28 & 0.25 & 12.6 & 4.0 & 0.5 & 11.2 & 16.6 & 6.6 & L. \\
\hline 19 & $34^{\circ} 43^{\prime}$ & $47^{\circ} 31^{\prime}$ & 0.23 & 7.63 & 41 & 0.87 & 15.4 & 6.1 & 0.4 & 23 & 43.6 & 1.75 & Si.C.L. \\
\hline 20 & $33^{\circ} 32^{\prime}$ & $48^{\circ} 20^{\prime}$ & 0.21 & 7.76 & 54 & 0.98 & 9.6 & 18.2 & 0.3 & 38.4 & 1.2 & 4.0 & C. \\
\hline 21 & $25^{\circ} 38^{\prime}$ & $58^{\circ} 31^{\prime}$ & 0.88 & 8.08 & 33 & 0.11 & 1.2 & 3.0 & 0.3 & 9.2 & 20.7 & 42.5 & S.L. \\
\hline
\end{tabular}

Soil regions: (1) DarehBid, (2) Lenjan, (3) Talkhuncheh, (4) Darin, (5) Balestan, (6) Bushgan, (7) EmamZadeh, (8) GhasemKhani, (9) EbrahimAbad, (10) GonAbad, (11) NajmAbad, (12) Jazooshi, (13) Kharghani, (14) Sarvestan, (15) Dogh, (16) Shurjeh, (17) Ghadamgah, (18) CamSorkh, (19) SharifAbad, (20) TappehGhachi, and (21) Sahel. E.C. electrical conductivity, S.P. saturation percentage, O.C. organic matter, Avail. P. available phosphorus, CEC cation exchange capacity, Avail. $S$. available sulfur

not high in organic carbon, ranging between 0.06 and $0.98 \%$, with the average organic carbon of $0.5 \%$. CaCO3, clay, and cation exchange capacity (CEC) were in the range of 10-842 $\mathrm{g} / \mathrm{kg}, 80-530 \mathrm{~g} / \mathrm{kg}$, and $7-38.4 \mathrm{cmol} / \mathrm{kg}$ soil, respectively. The available $\mathrm{P}$ and $\mathrm{S}$ were in the ranges of $2-20.2$ and $2-837.5$ $\mathrm{mg} / \mathrm{kg}$, and $\mathrm{Fe}$ and $\mathrm{Zn}$ ranged from 0.8 to 18.2 and $0.2-1$ $\mathrm{mg} / \mathrm{kg}$, respectively (Table 1). Analyses of variance indicated the significant effects of soil moisture, organic matter, and their interactions on soil chemical properties including $\mathrm{pH}$, $\mathrm{EC}$, and $\mathrm{OC}$ in the experimental regions (Table 2).

\subsection{Soil acidity}

The effects of both experimental treatments were significant on soil acidity. There were not clear trends of experimental treatments on soil $\mathrm{pH}$. However, in the V1 treatment, BI significantly decreased soil acidity, in V2 there were not any effects of organic matter, in V3, BI significantly increased soil $\mathrm{pH}$, and in V4, WS significantly decreased soil acidity, while the effect of BI was not significant. The trend of $\mathrm{pH}$ variation was not significant at the field capacity (FC) moisture. The effects of experimental treatments were highly variable on soil acidity as the least $\mathrm{pH}$ value was related to treatment $\mathrm{M} 2$ at $\mathrm{V} 4$ (Fig. 2). S8 at V4 had the highest soil $\mathrm{pH}(8.80)$, and $\mathrm{S} 6$ at V1 had the least soil $\mathrm{pH}$ (7.74).

With respect to the properties of the experimental soils, the effects of organic matter at different soil moisture levels appeared differently. Accordingly, the least $\mathrm{pH}$ 's were related to region 6 at $\mathrm{V} 1$, and the highest $\mathrm{pH}$ 's were related to region 8 affected by soil moisture levels and sources of organic matter. In most cases, the use of WS significantly increased soil $\mathrm{pH}$ compared with control and BI treatments (Fig. 2a-d). BI resulted in the least $\mathrm{pH}(7.84)$ in $\mathrm{S6}$, and WS resulted in the highest $\mathrm{pH}$ (8.87) in $\mathrm{S} 8$.

\subsection{Soil salinity}

The results indicated that the effects of different sources of fertilization including control $(2.9 \mathrm{dS} / \mathrm{m})$ and WS $(2.8 \mathrm{dS} / \mathrm{m})$ on soil salinity were not significantly different; however, soil salinity by BI was significantly $(3.1 \mathrm{dS} / \mathrm{m})$ higher than the other treatments. The effects of soil moisture on soil salinity 
Table 2 Organic carbon, salinity, and acidity of the experimental soils affected by the sources of organic matter

\begin{tabular}{|c|c|c|c|c|c|}
\hline \multirow[t]{2}{*}{ Soil } & \multirow[t]{2}{*}{ S.V. } & \multirow[t]{2}{*}{ d.f. } & \multicolumn{3}{|l|}{ S.S. } \\
\hline & & & $\mathrm{OC}$ & $\mathrm{EC}$ & $\mathrm{pH}$ \\
\hline \multirow[t]{5}{*}{1} & M. & 3 & 0.2 & $0.017 * *$ & 0.14 \\
\hline & O.M. & 2 & 0.2 & $0.09 * *$ & $0.64 * *$ \\
\hline & M. * O.M. & 6 & 0.08 & $0.01 * *$ & 0.11 \\
\hline & Error & 12 & 0.09 & 0.003 & 0.055 \\
\hline & C.V. (\%) & - & 3.7 & 7.2 & 37.6 \\
\hline \multirow[t]{5}{*}{2} & M. & 3 & $0.05^{* *}$ & $0.49 *$ & $0.05 * *$ \\
\hline & O.M. & 2 & $0.05^{* *}$ & 0.19 & $0.85^{* *}$ \\
\hline & M. * O.M. & 6 & $0.02 * *$ & 0.11 & $0.02 * *$ \\
\hline & Error & 12 & 0.006 & 0.09 & $0.002 * *$ \\
\hline & C.V.(\%) & - & 0.97 & 4.4 & 5.2 \\
\hline \multirow[t]{5}{*}{3} & M. & 3 & 0.017 & 0.0007 & $0.10^{* *}$ \\
\hline & O.M. & 2 & $2.07 * *$ & $0.05 * *$ & $0.09 *$ \\
\hline & M. * O.M. & 6 & 0.02 & 0.0005 & $0.06^{*}$ \\
\hline & Error & 12 & 0.009 & 0.0003 & 0.01 \\
\hline & C.V. (\%) & - & 16.18 & 4.8 & 1.4 \\
\hline \multirow[t]{5}{*}{4} & M. & 3 & $0.06^{* *}$ & $0.02 * *$ & 0.2 \\
\hline & O.M. & 2 & 0.6 & $0.06^{* *}$ & 0.1 \\
\hline & M. * O.M. & 6 & 0.01 & $0.006^{* *}$ & 0.1 \\
\hline & Error & 12 & 0.005 & 0.0003 & 0.09 \\
\hline & C.V. (\%) & - & 7.3 & 6.2 & 3.7 \\
\hline \multirow[t]{5}{*}{5} & M. & 3 & $0.4^{* *}$ & $0.02 * *$ & 0.04 \\
\hline & O.M. & 2 & $0.07 *$ & $0.1 * *$ & $0.8 * *$ \\
\hline & M. * O.M. & 6 & $0.2 * *$ & $0.007 * *$ & 0.02 \\
\hline & Error & 12 & 0.01 & $0.001 * *$ & 0.02 \\
\hline & C.V. (\%) & - & 1.3 & 14.7 & 15.2 \\
\hline \multirow[t]{5}{*}{6} & M. & 3 & 0.006 & $0.2 * *$ & $0.17 * *$ \\
\hline & O.M. & 2 & $0.8^{* *}$ & $0.3 * *$ & $0.09 * *$ \\
\hline & M. * O.M. & 6 & 0.01 & 0.06 & $0.05^{* *}$ \\
\hline & Error & 12 & 0.02 & 0.02 & 0.007 \\
\hline & C.V. (\%) & - & 13.2 & 5.5 & 1.11 \\
\hline \multirow[t]{5}{*}{7} & M. & 3 & $0.05^{* *}$ & $0.18^{* *}$ & 0.05 \\
\hline & O.M. & 2 & $0.9^{* *}$ & $0.15^{* *}$ & 0.05 \\
\hline & M. * O.M. & 6 & $0.01 *$ & 0.02 & 0.01 \\
\hline & Error & 12 & 0.004 & 0.01 & 0.03 \\
\hline & C.V.(\%) & - & 5.9 & 11.1 & 2.3 \\
\hline \multirow[t]{5}{*}{8} & M. & 3 & 0.004 & $0.016^{* *}$ & 0.04 \\
\hline & O.M. & 2 & $0.67 * *$ & $0.07 * *$ & $0.37 * *$ \\
\hline & M. * O.M. & 6 & $0.01 *$ & $0.009 * *$ & 0.04 \\
\hline & Error & 12 & 0.004 & 0.001 & 0.02 \\
\hline & C.V.(\%) & - & 10.2 & 9.4 & 1.7 \\
\hline \multirow[t]{5}{*}{9} & M. & 3 & $0.3 * *$ & 0.35 & 0.02 \\
\hline & O.M. & 2 & $0.7 * *$ & 0.01 & $0.13 * *$ \\
\hline & M. * O.M. & 6 & $0.02 *$ & $0.68 *$ & 0.01 \\
\hline & Error & 12 & 0.005 & 0.17 & 0.01 \\
\hline & C.V.(\%) & - & 11.4 & 3.4 & 1.2 \\
\hline \multirow[t]{5}{*}{10} & M. & 3 & 0.019 & $0.005^{*}$ & 0.004 \\
\hline & O.M. & 2 & $0.8^{* *}$ & $0.081 * *$ & $0.04 * *$ \\
\hline & M. * O.M. & 6 & 0.008 & $0.003 * *$ & 0.019 \\
\hline & Error & 12 & 0.006 & 0.001 & 0.003 \\
\hline & C.V.(\%) & - & 16.8 & 10.36 & 0.73 \\
\hline 11 & M. & 3 & $0.1 * *$ & 0.001 & 0.05 \\
\hline & O.M. & 2 & $1.6^{* *}$ & $0.13 * *$ & 0.005 \\
\hline & M. * O.M. & 6 & $0.01 *$ & 0.0036 & 0.021 \\
\hline & Error & 12 & 0.005 & 0.0033 & 0.024 \\
\hline & C.V.(\%) & - & 10.33 & 19.58 & 1.84 \\
\hline 12 & M. & 3 & $0.2 * *$ & 21.7 & $0.08^{* *}$ \\
\hline & O.M. & 2 & $1.3^{* *}$ & 0.53 & $0.09 * *$ \\
\hline & M. * O.M. & 6 & $0.03^{* *}$ & 9.4 & $0.01 *$ \\
\hline & Error & 12 & 0.002 & 8.1 & 0.006 \\
\hline & C.V.(\%) & - & 4.5 & 12.56 & 0.96 \\
\hline 13 & M. & 3 & $0.02 *$ & $0.6^{* *}$ & $0.03 *$ \\
\hline & O.M. & 2 & $0.9 * *$ & $0.64 * *$ & 0.0009 \\
\hline
\end{tabular}

Table 2 (continued)

\begin{tabular}{|c|c|c|c|c|c|}
\hline \multirow[t]{2}{*}{ Soil } & \multirow[t]{2}{*}{ S.V. } & \multirow[t]{2}{*}{ d.f. } & \multicolumn{3}{|l|}{ S.S. } \\
\hline & & & $\mathrm{OC}$ & $\mathrm{EC}$ & $\mathrm{pH}$ \\
\hline & M. * O.M. & 6 & 0.012 & $0.28 * *$ & $0.03 * *$ \\
\hline & Error & 12 & 0.005 & 0.05 & 0.006 \\
\hline & C.V.(\%) & - & 6.16 & 6.06 & 0.99 \\
\hline \multirow[t]{5}{*}{14} & M. & 3 & $0.3 * *$ & 0.08 & 0.031 \\
\hline & O.M. & 2 & $0.89^{* *}$ & $0.3^{* *}$ & 0.0005 \\
\hline & M. * O.M. & 6 & $0.03 * *$ & 0.04 & 0.006 \\
\hline & Error & 12 & 0.003 & 0.03 & 0.01 \\
\hline & C.V.(\%) & - & 7.3 & 4.7 & 1.26 \\
\hline \multirow[t]{5}{*}{15} & M. & 3 & $0.29 * *$ & $0.32 * *$ & $0.055^{*}$ \\
\hline & O.M. & 2 & $0.8^{* *}$ & $0.08 * *$ & 0.007 \\
\hline & M. * O.M. & 6 & $0.009^{* *}$ & 0.01 & 0.033 \\
\hline & Error & 12 & 0.001 & 12.07 & 0.01 \\
\hline & C.V.(\%) & - & 3.8 & - & 1.29 \\
\hline \multirow[t]{5}{*}{16} & M. & 3 & 0.02 & $1.22 * *$ & $0.05^{* *}$ \\
\hline & O.M. & 2 & $0.8^{* *}$ & $1.17 * *$ & $0.02 *$ \\
\hline & M. * O.M. & 6 & 0.004 & 0.05 & 0.003 \\
\hline & Error & 12 & 0.01 & 0.08 & 0.006 \\
\hline & C.V.(\%) & - & 11.4 & 15.5 & 0.96 \\
\hline \multirow[t]{5}{*}{17} & M. & 3 & $0.03 *$ & $0.038^{*}$ & 0.085 \\
\hline & O.M. & 2 & $0.62 * *$ & $0.17 * *$ & 0.098 \\
\hline & M. * O.M. & 6 & $0.01 *$ & 0.016 & 0.05 \\
\hline & Error & 12 & 0.005 & 0.009 & 0.04 \\
\hline & C.V.(\%) & - & 10.7 & 19 & 2.58 \\
\hline \multirow[t]{5}{*}{18} & M. & 3 & $0.01 *$ & 0.04 & 0.033 \\
\hline & O.M. & 2 & $0.64 * *$ & $0.06^{*}$ & $0.047 *$ \\
\hline & M. * O.M. & 6 & $0.01 *$ & $0.03^{*}$ & 0.014 \\
\hline & Error & 12 & 0.002 & 0.01 & 0.010 \\
\hline & C.V.(\%) & - & 8.0 & 13.3 & 1.21 \\
\hline \multirow[t]{5}{*}{19} & M. & 3 & $0.02 * *$ & $0.07 * *$ & 0.012 \\
\hline & O.M. & 2 & $0.64 * *$ & $0.05 * *$ & 0.01 \\
\hline & M. * O.M. & 6 & $0.01 * *$ & $0.01 * *$ & 0.005 \\
\hline & Error & 12 & 0.003 & 0.001 & 0.025 \\
\hline & C.V.(\%) & - & 4.8 & 11.7 & 1.92 \\
\hline \multirow[t]{5}{*}{20} & M. & 3 & $0.083^{*}$ & $0.12 * *$ & 0.01 \\
\hline & O.M. & 2 & $1.18 * *$ & $0.1 * *$ & 0.01 \\
\hline & M. * O.M. & 6 & 0.02 & $0.01 * *$ & 0.01 \\
\hline & Error & 12 & 0.01 & 0.001 & 0.01 \\
\hline & C.V.(\%) & - & 10.4 & 12.8 & 1.4 \\
\hline \multirow[t]{5}{*}{21} & M. & 3 & 0.016 & 0.01 & $0.02 *$ \\
\hline & O.M. & 2 & $0.71 * *$ & $0.12 * *$ & $0.03 * *$ \\
\hline & M. * O.M. & 6 & 0.006 & 0.03 & $0.04 * *$ \\
\hline & Error & 12 & 0.004 & 0.014 & 0.004 \\
\hline & C.V.(\%) & - & 12.7 & 8.5 & 0.77 \\
\hline
\end{tabular}

*, **: significant at $P=0.05$ and 0.01 , respectively

were significantly higher in V2 (variable soil moisture of field capacity) (3.16 dS/m) compared the moisture levels (ranging from 2.84 to $2.93 \mathrm{dS} / \mathrm{m}$ ). S5 and V4 resulted in the least EC $(0.17 \mathrm{dS} / \mathrm{m})$, and S12 and V2 had the highest EC (24.67 dS/ $\mathrm{m})$. S3 and the control treatment of OM resulted in the least EC $(0.16 \mathrm{dS} / \mathrm{m})$, and $\mathrm{S} 12$ and BI resulted in the highest EC (23.04 dS/m).

\subsection{Soil organic matter}

The effects of experimental treatments on soil organic matter were significant, and both organic treatments (WS (0.89\%) 
and BI (1.20\%)) significantly increased soil organic matter $(0.49 \%)$ compared with the control treatment. However, according to the results, the effects of BI were more pronounced on enhancing soil organic matter, than the WS treatment. The combination of S21 and V3 resulted in the least $(0.20 \%)$ and S16 and V4 in the highest $(1.47 \%)$ OC. S10 and control treatment of OM had the least $(0.06 \%) \mathrm{OC}$ and S16 and BI had the highest $(1.64 \%)$ OC.

\subsection{Microbial biomass carbon}

According to the analysis of variance, the effect of organic fertilization was significant on $\mathrm{MBC}$ in different experimental regions (Table 3). Similar to the effects of the organic fertilization treatments on soil organic matter, the use of WS $(524.9 \mathrm{mg} / \mathrm{kg})$ and BI $(885.1 \mathrm{mg} / \mathrm{kg})$ significantly increased $\mathrm{MBC}$, compared with the control treatment $(221.5 \mathrm{mg} / \mathrm{kg})$, and the effects of BI were more pronounced than the effects of WS in the soils of different experimental regions (Fig. 3a-d). S17 and the control treatment of organic matter resulted in the least $(43.1 \mathrm{mg} / \mathrm{kg})$ and $\mathrm{S} 16$ and BI resulted in the highest $(2947.4 \mathrm{mg} / \mathrm{kg})$ MBC.

\section{Discussion}

\subsection{Soil physicochemical properties}

Investigating soil properties affected by varying soil moisture (drying and rewetting cycles) and different sources of organic matter is of significance for the optimum production of agricultural crops. In this research, different parts of Iran, with a high variation of soil physical, chemical, and biological properties were selected so that the obtained results can be broadly interpreted and used. The significant effects of the experimental treatments and their interactions on soil $\mathrm{pH}$, salinity, organic matter, and $\mathrm{MBC}$ indicated that it is possible to alter such soil properties in a favorable way, so that the efficiency of agricultural fields is enhanced. Luo et al. [31] also found that the use of biochar significantly increased soil organic carbon and total $\mathrm{N}$, and as a result, biochar can be used for the optimization of fertilizer use.

According to Li et al. [25], the addition of biochar, similar to our results, increased soil $\mathrm{pH}$ and increased the efficiency of water and soil for crop production. Although researchers have indicated that it is possible to mitigate the negative effects of soil salinity on plant growth using the optimum rates of biochar, the increased solubility of different elements such as $\mathrm{Ca}^{2+}, \mathrm{Mg}^{2+}$, and $\mathrm{K}^{+}$(their presence in the soil solution) in
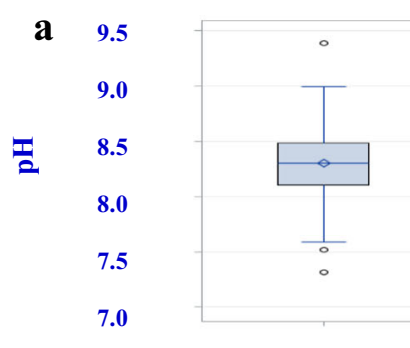

M1

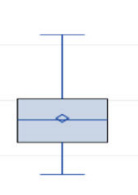

M2

Organic matter

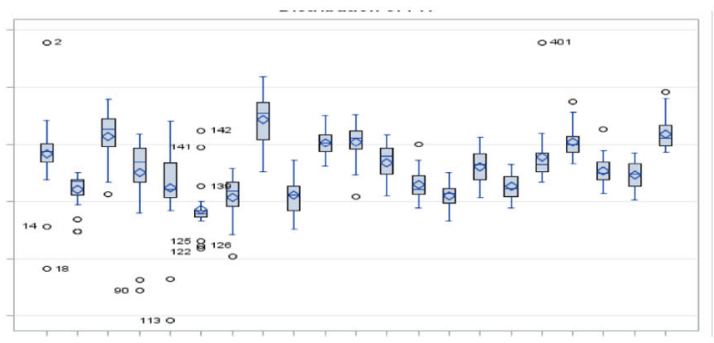

$\begin{array}{lllllllllllllllllllll}1 & 2 & 3 & 4 & 5 & 6 & 7 & 8 & 9 & 10 & 11 & 12 & 13 & 14 & 15 & 16 & 17 & 18 & 19 & 20 & 21\end{array}$ Soil type

Fig. 2 Soil pH affected by (a) organic matter (M), (b) soil moisture (V), (c) soil type, and (d) interaction of organic matter and soil moisture. Levels of organic matter $(\mathrm{M} 1=1$ (control), $\mathrm{M} 2=2$ (2\% wheat straw , $\mathrm{M} 3=3(2 \%$ biochar $))$ and moisture levels $(\mathrm{V} 1=1(0.2 \mathrm{FC}), \mathrm{V} 2=2(0.7$

b

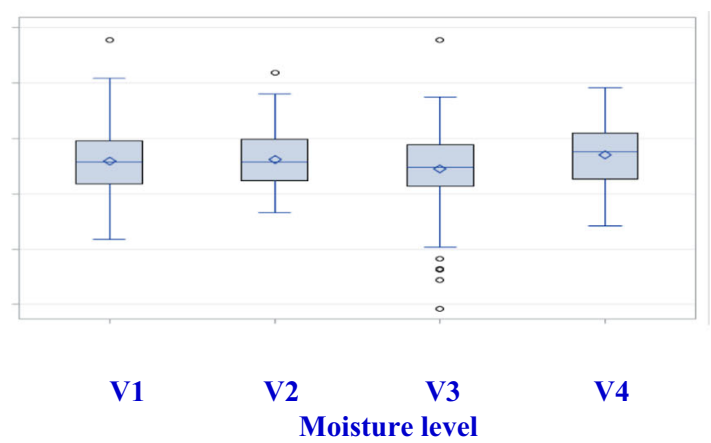

d

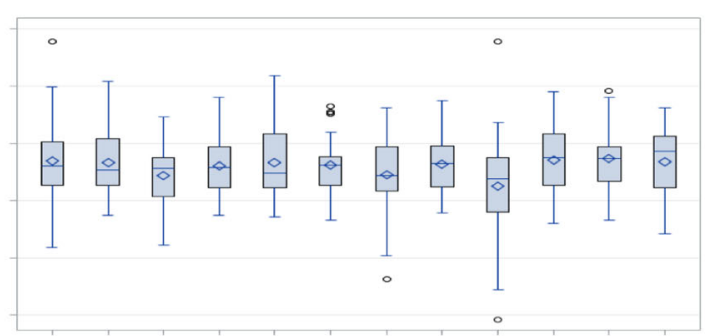

$\begin{array}{llllllllllll}1.0 & 1.1 & 1.2 & 2.0 & 2.1 & 2.2 & 3.0 & 3.1 & 3.2 & 4.0 & 4.1 & 4.2\end{array}$ Interaction of moisture and organic matter variable FC), V3= $3(0.7$ constant FC), and V4= 4 (saturated moisture)). The numbers in $\mathbf{d}$ stand for the combination of soil moisture $(1,2,3$, and $4)$ and organic matter $(0,1$, and 2$)$ 
Table 3 Microbial biomass carbon affected by the sources of organic matter

\begin{tabular}{|c|c|c|c|}
\hline Soil & S.V. & d.f. & $\mathrm{MBC}$ \\
\hline \multirow[t]{3}{*}{1} & O.C. & 2 & $92398 * *$ \\
\hline & Error & 3 & 243.9 \\
\hline & C.V. & - & 4.5 \\
\hline \multirow[t]{3}{*}{2} & O.C. & 2 & $200379 * *$ \\
\hline & Error & 3 & 647.2 \\
\hline & C.V. & - & 4.5 \\
\hline \multirow[t]{3}{*}{3} & O.C. & 2 & $117409 * *$ \\
\hline & Error & 3 & 645.1 \\
\hline & C.V. & - & 4.9 \\
\hline \multirow[t]{3}{*}{4} & O.C. & 2 & $344871 * *$ \\
\hline & Error & 3 & 5194.6 \\
\hline & C.V. & - & 9.2 \\
\hline \multirow[t]{3}{*}{5} & O.C. & 2 & $93381 * *$ \\
\hline & Error & 3 & 220 \\
\hline & C.V. & - & 3.5 \\
\hline \multirow[t]{3}{*}{6} & O.C. & 2 & $100381 * *$ \\
\hline & Error & 3 & 759 \\
\hline & C.V. & - & 5.2 \\
\hline \multirow[t]{3}{*}{7} & O.C. & 2 & $186165^{* *}$ \\
\hline & Error & 3 & 1540.7 \\
\hline & C.V. & - & 6.8 \\
\hline \multirow[t]{3}{*}{8} & O.C. & 2 & $347054 * *$ \\
\hline & Error & 3 & 456.3 \\
\hline & C.V. & - & 3.8 \\
\hline \multirow[t]{3}{*}{9} & O.C. & 2 & $57392 * *$ \\
\hline & Error & 3 & 361.1 \\
\hline & C.V. & - & 7.8 \\
\hline \multirow[t]{3}{*}{10} & O.C. & 2 & $174531 * *$ \\
\hline & Error & 3 & 365.3 \\
\hline & C.V. & - & 3.8 \\
\hline \multirow[t]{3}{*}{11} & O.C. & 2 & $304199 * *$ \\
\hline & Error & 3 & 1438 \\
\hline & C.V. & - & 4.9 \\
\hline \multirow[t]{3}{*}{12} & O.C. & 2 & $514104 * *$ \\
\hline & Error & 3 & 1376.3 \\
\hline & C.V. & - & 4.5 \\
\hline \multirow[t]{3}{*}{13} & O.C. & 2 & $327738 * *$ \\
\hline & Error & 3 & 797.4 \\
\hline & C.V. & - & 4.1 \\
\hline \multirow[t]{3}{*}{14} & O.C. & 2 & $45683 * *$ \\
\hline & Error & 3 & 809.6 \\
\hline & C.V. & - & 5.4 \\
\hline \multirow[t]{3}{*}{15} & O.C. & 2 & $86069 * *$ \\
\hline & Error & 3 & 928.5 \\
\hline & C.V. & - & 6.8 \\
\hline \multirow[t]{3}{*}{16} & O.C. & 2 & $68199 * *$ \\
\hline & Error & 3 & 385 \\
\hline & C.V. & - & 3.8 \\
\hline
\end{tabular}

the soil when treated with BI, at the higher rates, can be the most important reason increasing soil salinity $[17,52]$ in our research.

Another important aspect about the present research is the high variability of the selected soil properties, including salinity, $\mathrm{pH}$, saturation percentage, organic $\mathrm{C}$, available, $\mathrm{P}, \mathrm{Fe}, \mathrm{Zn}, \mathrm{CEC}$, and $\mathrm{CaCO}_{3}$, which can also significantly affect the productivity of the tested soils. Due to the presence of a wide range of soil textures, it can be the important source of variation. The texture of soil affects different soil chemical properties including the availability of nutrients. In the meanwhile, the interaction of such properties with the tested treatments can also determine the response of the soils to the use of different sources of organic matter at varying soil moistures. Dai et al. [8], by a meta-analysis, indicated that plant response to biochar is determined by the physicochemical properties of biochar and soil [11-13]. Similar to our results, $\mathrm{Li}$ et al. [25] found that with increasing the rate of biochar, soil salinity increased.

Different types of soils revealed distinct range of properties. The soils differed from non-saline to saline, the $\mathrm{pH}$ 's were 


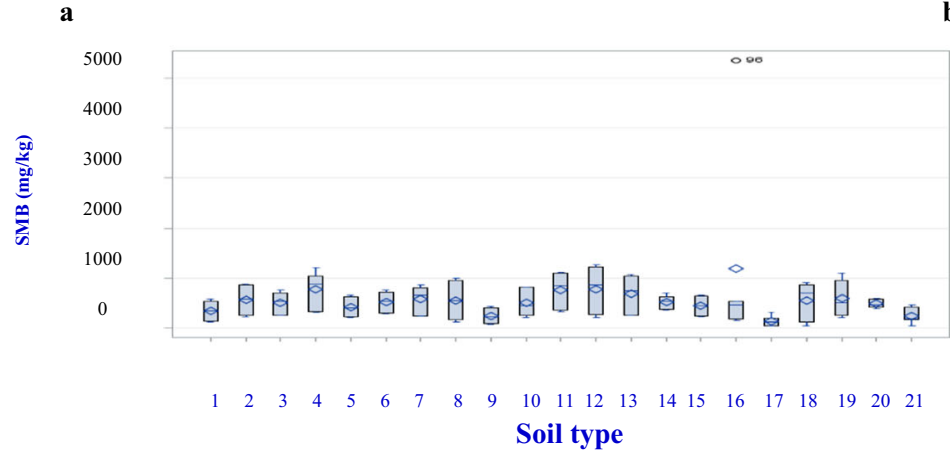

c

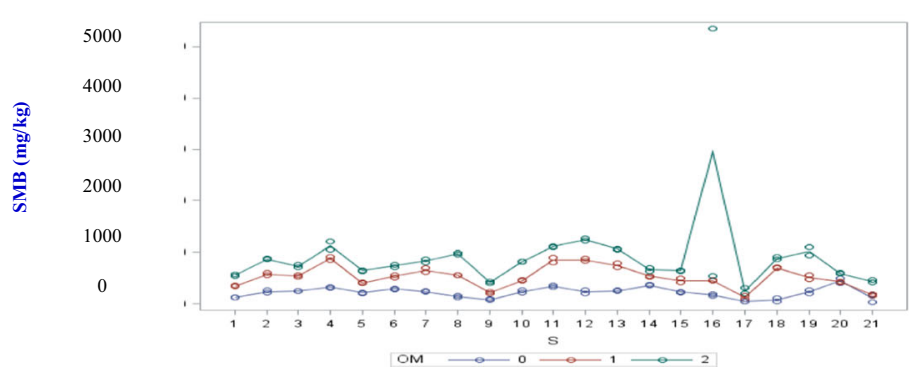

SMB affected by the variation of organic matter $(O M)$ at different soil types

Fig. 3 Soil microbial biomass (SMB) affected by (a) soil type, (b) organic matter, (c) the variation of organic matter $(\mathrm{OM})$ at different soil types, and (d) the interaction of soil type and organic matter. Levels of organic matter $(\mathrm{M} 1=1$ (control), M2 $=2$ ( $2 \%$ wheat straw $(, \mathrm{M} 3=3(2 \%$ biochar $)$ ) and moisture levels $(\mathrm{V} 1=1(0.2 \mathrm{FC}), \mathrm{V} 2=2(0.7$ variable $\mathrm{FC}), \mathrm{V} 3=3(0.7$ constant FC), and $\mathrm{V} 4=4$ (saturated moisture)) of the soil regions: (1)

alkaline, and high variability of soil saturation, which definitely affects availability of water for plant use and the redox potential of soil. However, organic carbon was deficient in the soils. Although soil texture significantly affects different soil physical and chemical properties, including the availability of nutrients, water holding capacity and CEC, organic matter is also an important factor significantly affecting the such properties. The deficiency of organic matter in the tested soils is an indicator confirming the need for treating the soils with WS and BI.

\subsection{Soil physicochemical properties affected by biochar and wheat straw}

According to our results, although the two sources of organic fertilization including WS and BI significantly affected different soil properties including $\mathrm{pH}$, salinity, organic matter, and soil MBC, the effects of BI were more pronounced. This can be due to the higher percentage of $\mathrm{C}$ in $\mathrm{BI}(61 \%)$ than WS $(53.74 \%)$ affecting plant use and microbial activities. It is because the process of pyrolysis significantly increases the

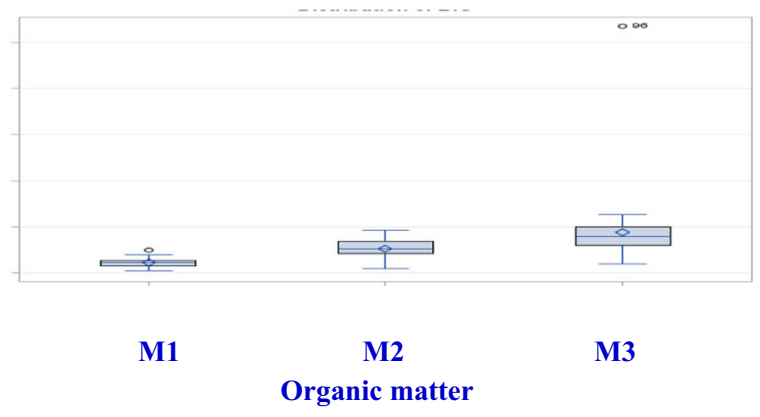

d

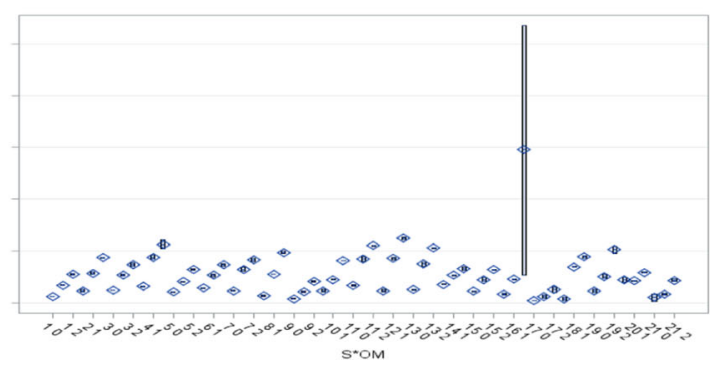

The interaction of soil and organic matter affecting SMB

DarehBid, (2) Lenjan, (3) Talkhuncheh, (4) Darin, (5) Balestan, (6) Bushgan, (7) EmamZadeh, (8) GhasemKhani, (9) EbrahimAbad, (10) GonAbad, (11) NajmAbad, (12) Jazooshi, (13) Kharghani, (14) Sarvestan, (15) Dogh, (16) Shurjeh, (17) Ghadamgah, (18) CamSorkh, (19) SharifAbad, (20) TappehGhachi, and (21) Sahel. The numbers in d are the combination of soil type (1-21) and organic matter $(0,1$, and 2$)$

degradation rate of organic matter in $\mathrm{BI}$, and as a result, the present $\mathrm{N}$ and $\mathrm{C}$ can be more easily used by plants and microbes. Similarly, Sun et al. [50] found that although the effects of manure were more pronounced on soil properties such as microbial abundance and diversity, WS was also able to increase bacterial population, but not diversity, by increasing soil $\mathrm{pH}$ and the availability of different soil nutrients including C, N, and P [44]. Similar to our results, Pokharel et al. [38], conducting a global meta-analysis, found that biochar can significantly increase soil microbial biomass $\mathrm{C}$ and enzymatic activities. They accordingly indicated that the use of biochar is a suitable method for reviving the fertility of soils and increasing plant productivity, especially in areas with not sufficient amount of organic matter [2].

\subsection{Drying and rewetting affecting soil physicochemical properties}

The effects of drying and rewetting (moisture fluctuation) on soil physical, chemical, and biological properties have been investigated by researchers. The fluctuation of soil moisture is 
a function of rainfall, irrigation, and temperature, which are more inconsistent under arid and semi-arid conditions $[14,16$, 41]. Due to rewetting. (1) the availability of food and bacterial activity increases quickly, and (2) the degradation of soil aggregates releases the immobilized organic matter, mineralized by soil microbes [55]. The higher the number of drying and rewetting cycles, the less the microbial biomass and activity, which is due to higher microbial decomposition and carbon reduction by the soil microbes during the rewetting process. Microbial activity, subjected to drying and rewetting, is a function of soil type affecting soil moisture, organic matter, and aggregation as well as their interactions. Drying and rewetting may also decrease microbial population and subsequent nutrient release $[15,41,55]$.

\subsection{Biochar affecting soil pH}

According to the results, the use of $\mathrm{BI}$ at V1 significantly increased soil $\mathrm{pH}$, which is similar to the results by Smebye et al. [47]. However, at the higher levels of soil moisture, soil $\mathrm{pH}$ was not increased by $\mathrm{BI}$ indicating that soil moisture is a determining factor in the alteration of soil $\mathrm{pH}$ by BI (analysis of variance indicated significant interactions between soil moisture and BI). This can be due to the alteration of soil oxidation/reduction potential under higher moisture levels, because with increasing the soil moisture, and due to less oxygen, the conditions are more favorable for the reduction of the elements in the soil decreasing soil $\mathrm{pH}$.

The use of BI increases soil $\mathrm{pH}$ and the availability of soil organic matter absorbed onto soil particles affecting different soil properties including soil microbial activities [47, 51]. The strong binding of BI with cations such as $\mathrm{Ca}^{2+}$ and $\mathrm{Mg}^{2+}$, compared with the monovalent cations such as $\mathrm{Na}^{+}$and $\mathrm{K}^{+}$, can explain $\mathrm{pH}$ increase in the soil treated with $\mathrm{BI}$, resulting in the higher absorption of cations by soil colloids. Similarly, [5] found that the use of biochar increases soil $\mathrm{pH}$. Wu et al. [54] indicated that biochar is more effective than lime to enhance soil $\mathrm{pH}$ in acidic soil and improve fruit quality.

\subsection{Biochar and soil organic C}

Carbon presence in BI increases soil organic carbon, which can be available for plant and microbes in different forms such as dissolved organic carbon (in water, acidic and basic), affecting (1) plant and microbial growth, (2) soil properties, and (3) soil carbon and pollutant sequestration [9, 28, 39]. BI colloidal property is one important aspect affecting soil chemistry such as nutrient absorption and release or cation exchange capacity (CEC) and soil $\mathrm{pH}$ as well as soil physics such as water holding capacity, soil porosity, and hydraulic conductivity. Such soil physical characteristics affect water movement containing nutrients and dissolved organic compounds into the soil micro- and macropores [28, 29, 36].

\subsection{Biochar and soil microbial properties}

Biochar as a source of carbon can stimulate soil microbial activities affecting respiration of soil (increased production of $\mathrm{CO}_{2}$ ) as well as the biodegradation of soil organic compounds [34]. Although the analyses of phospholipid fatty acids indicated that during the first 16 weeks of the incubation study the microbial population decreased compared with control, it increased from week 16-24 indicating the gradual adoptability of soil microbes with the addition of BI. There was a shift in the soil microbial population toward the Gram-positive bacteria as the ratio of soil bacteria/soil fungi as well as Gram-negative bacteria/Grampositive bacteria decreased. In conclusion the authors indicated that BI can increase the population and activity of some bacterial species, affecting carbon sequestration (the increased production of $\mathrm{CO}_{2}$ ) and biodegradation of labile organic matter [34].

Such types of research are important due to the fluctuations of different soil properties such as moisture and salinity in the field, which are not constant in time and space affecting soil microbial properties. Interestingly, the use of organic matter can improve the properties of saline soils because the production of osmolytes requires a high amount of energy [55].

\section{Conclusion}

The effects of soil moisture (four different levels ranging from 0.2 field capacity to saturation) and organic matter (wheat straw and its biochar) on soil $\mathrm{pH}$, salinity, organic matter, and microbial biomass carbon were investigated in a 9-month incubation study using a wide range of soil types across Iran. There is not much data, to our knowledge, in this context. The results indicated that it is possible to alter such soil properties using wheat straw and biochar and make the conditions more favorable for plant growth and microbial activities. However, just WS was able to decrease soil salinity. BI salinity $(3.1 \mathrm{dS} / \mathrm{m})$ was significantly higher than WS $(2.8 \mathrm{dS} / \mathrm{m})$. Due to a higher percentage of $\mathrm{C}$ the organic treatments, especially, BI (61\%) significantly increased soil $\mathrm{OM}$ and $\mathrm{MBC}$ compared with the control treatment. The two sources of organic fertilization, as sources of food for the soil microbes, and due to having colloidal properties, increased soil $\mathrm{pH}, \mathrm{OM}$, and $\mathrm{MBC}$, though such effects were functions of varying soil moisture (drying and rewetting cycles). The important parameters of CEC and nutrient availability of soil colloids including organic matter determine soil $\mathrm{pH}$. The effects of BI, significantly affected by soil moisture, were more pronounced on soil parameters. The use of organic matter such as the ones tested in this research is strongly suggested, for improving the properties and increasing the production of agricultural fields. The combined use of WS and BI is recommendable for the improvement of soil chemical and biological properties in the arid and semi-arid areas of the world. 
Acknowledgements The authors would like to thank very much the international publisher, AbtinBerkeh Scientific Ltd. Company (https:// AbtinBerkeh.com), Isfahan, Iran, for editing the manuscript and revising it according to the journal format.

Author contribution All authors contributed equally to the manuscript.

Data availability The authors selected not to share data.

\section{Declarations}

Animal research Not applicable

Consent to participate Not applicable

Consent for publication Not applicable

Conflict of interest The authors declare no competing interests.

Open Access This article is licensed under a Creative Commons Attribution 4.0 International License, which permits use, sharing, adaptation, distribution and reproduction in any medium or format, as long as you give appropriate credit to the original author(s) and the source, provide a link to the Creative Commons licence, and indicate if changes were made. The images or other third party material in this article are included in the article's Creative Commons licence, unless indicated otherwise in a credit line to the material. If material is not included in the article's Creative Commons licence and your intended use is not permitted by statutory regulation or exceeds the permitted use, you will need to obtain permission directly from the copyright holder. To view a copy of this licence, visit http://creativecommons.org/licenses/by/4.0/.

\section{References}

1. Agegnehu G, Bass AM, Nelson PN, Bird MI (2016) Benefits of biochar, compost and biochar-compost for soil quality, maize yield and greenhouse gas emissions in a tropical agricultural soil. Sci Total Environ 543:295-306

2. Ahmad M, Wang X, Hilger TH, Luqman M, Nazli F, Hussain A, Zahir ZA, Latif M, Saeed Q, Malik HA, Mustafa A (2020) Evaluating biochar-microbe synergies for improved growth, yield of maize, and post-harvest soil characteristics in a semi-arid climate. Agronomy 10:1055

3. Asadi E, Ghehsareh AM, Moghadam EG, Hoodaji M, Zabihi HR (2019) Improvement of pomegranate colorless arils using iron and zinc fertilization. J Clean Prod 234:392-399

4. Bashir MA, Naveed M, Ahmad Z, Gao B, Mustafa A, NúñezDelgado A (2020) Combined application of biochar and sulfur regulated growth, physiological, antioxidant responses and $\mathrm{Cr}$ removal capacity of maize (Zea mays L.) in tannery polluted soils. J Environ Manag 259:110051

5. Buss W, Shepherd JG, Heal KV, Mašek O (2018) Spatial and temporal microscale $\mathrm{pH}$ change at the soil-biochar interface. Geoderma 331:50-52

6. Cakmak I, Kutman UB (2018) Agronomic biofortification of cereals with zinc: a review. Eur J Soil Sci 69:172-180

7. Cao Y, Yang B, Song Z, Wang H, He F, Han X (2016) Wheat straw biochar amendments on the removal of polycyclic aromatic hydrocarbons (PAHs) in contaminated soil. Ecotoxicol Environ Saf 130: $248-255$
8. Dai Y, Zheng H, Jiang Z, Xing B (2020) Combined effects of biochar properties and soil conditions on plant growth: a meta-analysis. Sci Total Environ 713:136635

9. Das SK, Mukherjee I (2020) Low cost biomass derived biochar amendment on persistence and sorption behaviour of flubendiamide in soil. Bull Environ Contam Toxicol 105:261-269

10. Das SK, Ghosh GK, Avasthe RK (2018) Preparation and characterization of biochars for their application as a soil amendment. Indian J Hill Farm 31:141-145

11. Das SK, Ghosh GK, Avasthe R (2020a) Ecotoxicological responses of weed biochar on seed germination and seedling growth in acidic soil. Environ Technol Innov 20:101074

12. Das SK, Ghosh GK, Avasthe R, (2020b) Evaluating biomasderived biochar on seed germination and early seedling growth of maize and black gram. Biomass Conversion and Biorefinery in press

13. Das SK, Ghosh GK, Avasthe R (2020c) Valorizing biomass to engineered biochar and its impact on soil, plant, water, and microbial dynamics: a review. Biomass Conversion and Biorefinery in press

14. Fierer N, Schimel JP (2002) Effects of drying-rewetting frequency on soil carbon and nitrogen transformations. Soil Biol Biochem 34: 777-787

15. Fierer N, Schimel JP (2003) A proposed mechanism for the pulse in carbon dioxide production commonly observed following the rapid rewetting of a dry soil. Soil Sci Soc Am J 67:798-805

16. Gehring CA (2017) Introduction: mycorrhizas and soil structure, moisture, and salinity. In: mycorrhizal mediation of soil, pp. 235 240. Elsevier. https://doi.org/10.1016/C2015-0-01928-1

17. Huang M, Zhang Z, Zhai Y, Lu P, Zhu C (2019) Effect of straw biochar on soil properties and wheat production under saline water irrigation. Agronomy 9:457

18. Jazini R, Soleimani M, Mirghaffari N (2018) Characterization of barley straw biochar produced in various temperatures and its effect on lead and cadmium removal from aqueous solutions. Water Environ J 32:125-133

19. Jenkinson DS, Ladd JN (1981) Microbial biomass in soil: measurement and turnover. in: Paul, E. A. and Ladd, J. N. (ed.) Soil biochemistry: New York Marcel Dekker, Inc. 5:415-471. https://doi. org/10.1016/0038-0717(91)90183-K

20. Jones AR, Gupta VV, Buckley S, Brackin R, Schmidt S, Dalal RC (2019) Drying and rewetting effects on organic matter mineralisation of contrasting soils after 36 years of storage. Geoderma 342:12-19

21. Kamran M, Malik Z, Parveen A, Zong Y, Abbasi GH, Rafiq MT, Shaaban M, Mustafa A, Bashir S, Rafay M, Mehmood S (2019) Biochar alleviates $\mathrm{Cd}$ phytotoxicity by minimizing bioavailability and oxidative stress in pak choi (Brassica chinensis L.) cultivated in Cd-polluted soil. J Environ Manag 250:109500

22. Kamran M, Malik Z, Parveen A, Huang L, Riaz M, Bashir S, Mustafa A, Abbasi GH, Xue B, Ali U (2020) Ameliorative effects of biochar on rapeseed (Brassica napus L.) growth and heavy metal immobilization in soil irrigated with untreated wastewater. J Plant Growth Regul 39:266-281

23. Lehmann J (2007) A handful of carbon. Nature 447:143-144

24. Li XG, Jia B, Lv J, Ma Q, Kuzyakov Y, Li FM (2017) Nitrogen fertilization decreases the decomposition of soil organic matter and plant residues in planted soils. Soil Biol Biochem 112:47-55

25. Li C, Xiong Y, Qu Z, Xu X, Huang Q, Huang G (2018) Impact of biochar addition on soil properties and water-fertilizer productivity of tomato in semi-arid region of Inner Mongolia, China. Geoderma 331:100-108

26. Li Y, Xing B, Ding Y, Han X, Wang S (2020) A critical review of the production and advanced utilization of biochar via selective pyrolysis of lignocellulosic biomass. Bioresour Technol 312: 123614 
27. Liu L, Fan S (2018) Removal of cadmium in aqueous solution using wheat straw biochar: effect of minerals and mechanism. Environ Sci Pollut Res 25:8688-8700

28. Liu C, Wang H, Li P, Xian Q, Tang X (2019a) Biochar's impact on dissolved organic matter (DOM) export from a cropland soil during natural rainfalls. Sci Total Environ 650:1988-1995

29. Liu CH, Chu W, Li H, Boyd SA, Teppen BJ, Mao J, Lehmann J, Zhang W (2019b) Quantification and characterization of dissolved organic carbon from biochars. Geoderma 335:161-169

30. Lopez-Sangil L, Hartley IP, Rovira P, Casals P, Sayer EJ (2018) Drying and rewetting conditions differentially affect the mineralization of fresh plant litter and extant soil organic matter. Soil Biol Biochem 124:81-89

31. Luo C, Yang J, Chen W, Han F (2020) Effect of biochar on soil properties on the Loess Plateau: results from field experiments. Geoderma 369:114323

32. Miransari M, Mackenzie AF (2015) Development of soil $\mathrm{N}$ testing for wheat production using soil residual mineral N. J Plant Nutr 38: 1995-2005

33. Miransari M, Bahrami HA, Rejali F, Malakouti MJ (2008) Using arbuscular mycorrhiza to alleviate the stress of soil compaction on wheat (Triticum aestivum L.) growth. Soil Biol Biochem 40:11971206

34. Mitchell PJ, Simpson AJ, Soong R, Simpson MJ (2015) Shifts in microbial community and water-extractable organic matter composition with biochar amendment in a temperate forest soil. Soil Biol Biochem 81:244-254

35. Moshabaki I, Tahmourespour F, Hoodaji AM, Ataabadi M, Mohammadi A (2018) Characterizing the new bacterial isolates of high yielding exopolysaccharides under hypersaline conditions. J Clean Prod 185:922-928

36. Mukherjee A, Zimmerman AR (2013) Organic carbon and nutrient release from a range of laboratory-produced biochars and biocharsoil mixtures. Geoderma 193:122-130

37. Naveed M, Mustafa A, Azhar SQTA, Kamran M, Zahir ZA, Núñez-Delgado A (2020) Burkholderia phytofirmans PsJN and tree twigs derived biochar together retrieved $\mathrm{Pb}$-induced growth, physiological and biochemical disturbances by minimizing its uptake and translocation in mung bean (Vigna radiata L.). J Environ Manag 257:109974

38. Pokharel P, Ma Z, Chang SX (2020) Biochar increases soil microbial biomass with changes in extra-and intracellular enzyme activities: a global meta-analysis. Biochar 2:65-79

39. Qu X, Fu H, Mao J, Ran Y, Zhang D, Zhu D (2016) Chemical and structural properties of dissolved black carbon released from biochars. Carbon 96:759-767

40. Schimel JP (2018) Life in dry soils: effects of drought on soil microbial communities and processes. Annu Rev Ecol Evol Syst 49:409-432

41. Schimel J, Balser TC, Wallenstein M (2007) Microbial stressresponse physiology and its implications for ecosystem function. Ecology 88:1386-1394

42. Schlesinger WH, Amundson R (2019) Managing for soil carbon sequestration: Let's get realistic. Glob Chang Biol 25:386-389

43. Sefati Z, Khalilimoghadam B, Nadian H (2019) Assessing urban soil quality by improving the method for soil environmental quality evaluation in a saline groundwater area of Iran. Catena 173:471480

44. Shahabifar J, Panahpour E, Moshiri F, Gholami A, Mostashari M (2019) The quantity/intensity relation is affected by chemical and organic P fertilization in calcareous soils. Ecotoxicol Environ Saf 172:144-151

45. Singh Brar B, Singh J, Singh G, Kaur G (2015) Effects of long term application of inorganic and organic fertilizers on soil organic carbon and physical properties in maize-wheat rotation. Agronomy 5: 220-238

46. Singh K, Mishra AK, Singh B, Singh RP, Patra DD (2016) Tillage effects on crop yield and physicochemical properties of sodic soils. Land Degrad Dev 27:223-230

47. Smebye A, Alling V, Vogt RD, Gadmar TC, Mulder J, Cornelissen G, Hale SE (2016) Biochar amendment to soil changes dissolved organic matter content and composition. Chemosphere 142:100 105

48. Song Z, Gao H, Zhu P, Peng C, Deng A, Zheng C, Mannaf MA, Islam MN, Zhang W (2015) Organic amendments increase corn yield by enhancing soil resilience to climate change. Crop J 3: $110-117$

49. Song D, Tang J, Xi X, Zhang S, Liang G, Zhou W, Wang X (2018) Responses of soil nutrients and microbial activities to additions of maize straw biochar and chemical fertilization in a calcareous soil. Eur J Soil Biol 84:1-10

50. Sun R, Zhang XX, Guo X, Wang D, Chu H (2015) Bacterial diversity in soils subjected to long-term chemical fertilization can be more stably maintained with the addition of livestock manure than wheat straw. Soil Biol Biochem 88:9-18

51. Uchimiya M, Lima IM, Klasson KT, Wartelle LH (2010) Contaminant immobilization and nutrient release by biochar soil amendment: roles of natural organic matter. Chemosphere 80:935940

52. Wu H, Lai C, Zeng G, Liang J, Chen J, Xu J, Dai J, Li X, Liu J, Chen M, Lu L (2017) The interactions of composting and biochar and their implications for soil amendment and pollution remediation: a review. Crit Rev Biotechnol 37:754-764

53. Wu P, Ata-Ul-Karim ST, Singh BP, Wang H, Wu T, Liu C, Fang G, Zhou D, Wang Y, Chen W (2019) A scientometric review of biochar research in the past 20 years (1998-2018). Biochar 1:23-43

54. Wu S, Zhang Y, Tan Q, Sun X, Wei W, Hu C (2020) Biochar is superior to lime in improving acidic soil properties and fruit quality of Satsuma mandarin. Sci Total Environ 714:136722

55. Yan N, Marschner P, Cao W, Zuo C, Qin W (2015) Influence of salinity and water content on soil microorganisms. Int Soil Water Conserv Res 3:316-323

56. Zamani, S., Naderi, M.R., Soleymani, A., Nasiri, B.M., 2020. Sunflower (Helianthus annuus L.) biochemical properties and seed components affected by potassium fertilization under drought conditions. Ecotoxicology and Environmental Safety 190, 110017.

Publisher's Note Springer Nature remains neutral with regard to jurisdictional claims in published maps and institutional affiliations. 